\title{
Új felismerések a pitvarfibrilláció genezisében és fenntartásában: az egyénre szabott kezelés lehetőségei
}

\author{
Kugler Szilvia dr. ${ }^{1}$ - Duray Gábor dr. ${ }^{2}$ - Préda István dr. ${ }^{1,2}$ \\ ${ }^{1}$ Semmelweis Egyetem, Általános Orvostudományi Kar, Városmajori Szív- és Érgyógyászati Klinika, Budapest \\ ${ }^{2}$ Magyar Honvédség Egészségügyi Központ, Kardiológiai Osztály, Budapest
}

\begin{abstract}
A pitvarfibrilláció prevalenciája a felnőttkorosztályban körülbelül három százalék. A ritmuskontroll céljából alkalmazott katéterablatiós terápia alapját jelenleg a pulmonalis vénák izolációja képezi, amelynek egyéves sikeraránya azonban többszöri beavatkozással sem emelhető $70 \%$ fölé. A beavatkozás hosszú távú eredményességét a pitvarokban bekövetkező elektromos és strukturális remodelláció korlátozza, amely az arrhythmia tartós fennmaradásához vezet. Az epicardialis zsírszöveti akkumuláció, a pitvari fibrosis, az autonóm idegrendszeri hatások, valamint a különféle arrhythmogen gócok lehetséges szerepét számos tanulmány elemezte. A pitvari epicardialis zsírszövet mennyisége, gyulladás indukálta fibroticus átalakulása és a myocardium zsíros infiltrációja, például obesitas esetén, pitvarfibrilláció fellépésére hajlamosít. Az autonóm szabályozás egyensúlyának megváltozása, például rendszeres sporttevékenység hatására, a triggerelt aktivitás fokozódása, valamint a pitvari refrakter periódus csökkenése révén indukálhat ritmuszavart. Hatékony terápia a lehetséges arrhythmogen trigger és szubsztrátmechanizmusok egyénre szabott komplex befolyásolása által valósulhat meg. A fibroticus folyamatok a renin-angiotenzin-aldoszteron rendszer gátlása révén lassíthatók. A neuromodulációs lehetőségek magukban foglalják a renalis denervációt, illetve a ganglionablatiót, és az antikoaguláns terápia pitvari remodellációt gátló hatásáról is ismertek adatok. A katéterablatiós beavatkozások lehetséges új irányait a jobb és bal pitvari lineáris laesiók alkalmazása, a heges területek homogenizálása mellett a komplex frakcionált pitvari elektrogramok, rotorok és az ectopiás fókuszok ablatiója képezik. Mindezek mellett kiemelt fontosságú a fennálló rizikófaktorok, úgymint obesitas, hyperlipidaemia, hypertonia, diabetes mellitus és obstruktív alvási apnoe hosszú távú, tervezett kezelése.
\end{abstract} Orv Hetil. 2018; 159(28): 1135-1145.

Kulcsszavak: pitvarfibrilláció, pitvari remodelláció, zsírszövet, autonóm idegrendszer, egyénre szabott kezelés

\section{Novel mechanisms in the initiation and maintenance of atrial fibrillation: tailored individual treatment}

Atrial fibrillation affects approximately three percent of the adults. Ablation strategies targeting the isolation of the pulmonary veins are the up-to-date cornerstones for atrial fibrillation ablations. However, a one-year success rate of repeated interventions is not more than $70 \%$. Long-term efficacy of catheter ablation is presumably limited by electrical and structural remodeling of the atria, which results in a progressive increase in the duration of atrial fibrillation to become sustained. The potential pathophysiological importance of the epicardial adipose tissue, atrial fibrosis, autonomic nervous system and arrhythmogenic foci are documented by several studies. Increased volume, inflammation induced transformation to fibrosis and myocardial infiltration of atrial subepicardial fat in obese patients result in higher risk of atrial fibrillation development. Changes in atrial autonomic innervation under some conditions including regular physical exercise strongly promote arrhythmogenesis via the mechanism of enhanced triggered activity or abbreviated atrial refractoriness. Individualized management of possible trigger and substrate mechanisms are proposed to provide a novel basis for the effective treatment of atrial fibrillation. Pro-fibrotic signalling pathways can be inhibited by the suppression of renin-angiotensin-aldosterone system. Neuromodulation strategies include renal sympathetic denervation and ganglionic plexi ablation. Anticoagulation therapy has also been shown to reduce the burden of abnormal atrial remodeling. Possible novel catheter ablation techniques are used for right or left atrial linear lesions, scar homogenization and catheter ablation of complex fractionated atrial electrograms, rotors or ectopic foci. Beside these new management strategies, clinical consideration of factors of particular risks as obesity, hyperlipidaemia, hypertension, diabetes and obstructive sleep apnoe are also essential. 
Keywords: atrial fibrillation, atrial remodeling, adipose tissue, autonomic nervous system, tailored individual treatment

Kugler Sz, Duray G, Préda I. [Novel mechanisms in the initiation and maintenance of atrial fibrillation: tailored individual treatment]. Orv Hetil. 2018; 159(28): 1135-1145.

(Beérkezett: 2018. február 12.; elfogadva: 2018. március 27.)

Semmelweis Ignác születésének 200. évfordulója évében a Szerkesztőség felkérésére készített tanulmány.

\begin{abstract}
Rövidítések
$\mathrm{BMI}=($ body mass index $)$ testtömegindex $;$ CFAE $=($ complex fractionated atrial electrogram) komplex frakcionált pitvari elektrogram; DE-MRI = (delayed enhancement MRI) késői kontraszthalmozásos technikával végzett szív-MRI; FACM = (fibrotic atrial cardiomyopathy) „kötőszövetes pitvari szívizomelfajulás"; FIRM = (focal impulse and rotor modulation $)$ fokális impulzus- és rotormoduláció; HMG-CoA = (3-hydroxy-3-methyl-glutaryl-coenzyme A) 3-hidroxi-3-metil-glutaril-koenzimA; LOM = (ligament of Marshall) Marshall-ligamentum; MRI $=($ magnetic resonance imaging $)$ mágneses rezonanciás képalkotás; NOAC $=($ novel oral anticoagulant $)$ új típusú orális antikoaguláns; OSAS = (obstructive sleep apnea syndrome) obstruktív alvási apnoe szindróma; PAR $=$ (protease-activated receptor) proteáz aktiválta receptor; $\mathrm{PF}=$ pitvarfibrilláció; $\mathrm{PVI}$ $=($ pulmonary vein isolation $)$ pulmonalisvéna-izoláció; RAAS $=$ (renin-angiotensin-aldosterone system) renin-angiotenzin-aldoszteron rendszer; $\mathrm{SC}=$ sinus coronarius; $\mathrm{VCI}=$ vena cava inferior; $\mathrm{VCS}=$ vena cava superior; $\mathrm{VP}=$ vena pulmonalis
\end{abstract}

A pitvarfibrilláció (PF) a leggyakoribb szívritmuszavar, amelynek prevalenciája a felnóttkorosztályban körülbelül $3 \%$, a betegségben 80 éves életkor felett pedig minden negyedik ember érintett. 2010-ben világszerte körülbelül 33,5 millió egyén szenvedett PF-ban [1]. Jellemzően progresszív lefolyású, vagyis a kezdetben csupán alkalmanként fellépő ritmuszavar az idő múlásával állandósul.

Általánosan elfogadott, hogy a ritmuszavart fokális elektromos aktiváció (trigger) váltja ki, amely nagyrészt a tüdővénák (vena pulmonalisok, VP-ok) területéról származik. Ezzel szemben a PF fenntartásában kiterjedt elektromos és strukturális pitvari remodelláció (arrhythmogen szubsztrát) szerepét feltételezik [2]. A PF-triggerek, valamint a remodellált pitvari szubsztrát komplex interakciójának fontos szerepet tulajdonítanak a perzisztens PF fennmaradásában.

A pitvari remodelláció kezdetben vélhetôen reverzíbilis folyamat, amelynek előidézői között olyan tényezőket tartanak nyilván, mint a hypertonia, a szívelégtelenség, a billentyúbetegség, a pitvar kötőszövetes átalakulása (fibrosis), az obstruktív alvási apnoe szindróma (OSAS), valamint a pitvari flattern, pitvari septumdefektus, amelyek a falfeszülés fokozása révén fejtik ki hatásukat [3]. Számos esetben már az első PF-epizód jelentkezése előtt bekövetkezik a pitvarok károsodása, remodellációja. A remodellált pitvarban fellépő PF napok-hetek alatt elektromos és strukturális változásokat idéz elő [4].
A pitvari károsodás és a következményes PF patomechanizmusában közrejátszik a renin-angiotenzin-aldoszteron rendszer (RAAS) aktivációja által kiváltott fibrosis, zsíros infiltráció, gyulladásos folyamatok, az autonóm idegrendszer egyensúlyának megbomlása, az ioncsatornák múködészavara, a fokozott alvadékonyság, valamint az oxidatív stressz által mediált folyamatok. A szöveti szinten történő szerkezeti változásokat múködésbeli funkciózavar kíséri, amely az elektrofiziológiai sajátosságok megváltozása révén fokozza a PF kialakulásának kockázatát és a ritmuszavar állandósulását. A PF hátterében álló szubsztrát a primer folyamat progresszióját okozva korlátozza a katéterablatiós beavatkozások sikerarányát [4-6] (1. táblázat).

1. táblázat |A pitvari remodelláció hátterében szerepet játszó tényezók

\begin{tabular}{lll}
\hline Klinikai faktorok & Szövettani faktorok & Patofiziológiai faktorok \\
\hline Hypertonia & Zsíros infiltráció & RAAS \\
Obesitas & Fibrosis & Oxidatív stressz \\
Diabetes mellitus & Gyulladás & Ioncsatornák \\
Szívelégtelenség & & Alvadási faktorok \\
Billentyúbetegség & & Autonóm idegrendszer \\
COPD & & Elektrofiziológiai tényezók \\
OSAS & & \\
\hline
\end{tabular}

COPD = krónikus obstruktív tüdőbetegség; OSAS = obstruktív alvási apnoe szindróma; RAAS = renin-angiotenzin-aldoszteron rendszer

A továbbiakban szeretnénk bemutatni a PF kiváltásában és fenntartásában jelenleg ismert patológiai folyamatokat, a triggerforrásként szolgáló anatómiai struktúrákat, elektromos kiváltó tényezőket, az epicardialis zsírszövet és a pitvarfal zsíros infiltrációját, az autonóm idegrendszer és az alvadási faktorok szerepét, valamint különféle genetikai tényezőket (1.ábra).

\section{A pitvarfibrilláció kiváltásában (trigger) forrásként szolgáló anatómiai struktúrák}

\section{Vena pulmonalis eredetü fokális impulzusok}

A VP-ok körül a bal pitvari myocardium nyúlványai által képzett szívizomhüvely területén jelen lévő ectopiás ingerképző fókuszok a PF kiváltása szempontjából kiemel- 


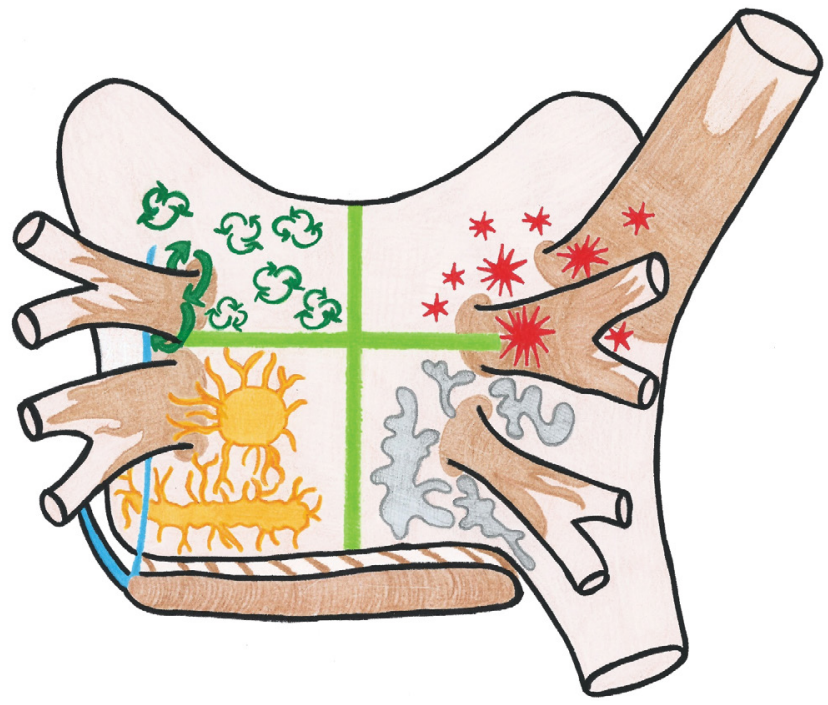

1. ábra

\begin{abstract}
A pitvarfibrilláció hátterében álló lehetséges mechanizmusok
A sémás ábra hátsó nézetben ábrázolja a bal és a jobb pitvart. A bal felsô pulmonalis véna körüli terület a reentrymechanizmust, a bal alsó negyed az autonóm ganglionok szerepét, a jobb felső pulmonalis véna a fokális triggereket, míg a jobb alsó negyed a heg jelentőségét szemlélteti
\end{abstract}

kedő jelentőséggel bírnak. Egy 1998-ban publikált, elektrofiziológiai vizsgálaton alapuló humán tanulmány eredményei arra utalnak, hogy a PF-paroxizmusok hátterében álló arrhythmogen gócok többsége a bal oldali, illetve a felső VP-ok területére lokalizálható, és a PF-t triggerelő ectopiás jelek rádiófrekvenciás ablatiót követően megszünnek [7]. A VP falában jelen lévő ectopiás pacemaker-sejtcsoportok a ritmuszavart fokozott automáciájuk révén válthatják ki, amelynek sejtélettani alapját a maximális diasztolés potenciál abszolút értékének csökkenése képezi [8].

Haïssaguerre és mtsai közleményének megjelenése óta a PF katéterablatiós terápiájának alapját a VP-szájadékok körkörös izolálása jelenti [7]. Ismert azonban, hogy a pulmonalisvéna-izoláció (PVI) egyéves sikeraránya - antiarrhythmiás gyógyszer alkalmazása nélkül - több beavatkozás esetén sem emelhető 70\% fölé [9]. A sikerarány független az alkalmazott módszertől (cryoablatio versus rádiófrekvenciás ablatio) [10].

A hatékonyságot több tényező korlátozza. Egyrészt a jelenlegi eszközökkel nem minden esetben hozható létre tartós laesio, következésképpen gyakran kiújul a VP-ok és a bal pitvar között kapcsolatot teremtő szívizomhüvely vezetőképessége, az ablatio során létesített hegben ingerületvezetésre képes rések keletkeznek. Másrészt jelenleg még nem ismertek kellően a PF-t fenntartó mechanizmusok [11].

\section{Nem vena pulmonalis eredetü fokális impulzusok}

Egy tanulmány tanúsága szerint a PF-ablatióban részesülő betegek esetében akár 11\%-ban nem VP-eredetű góc az indukált tartós PF forrása [12]. Az indukált nem tartós pitvari arrhythmiák esetén ez az arány még jelentősebb, akár $60 \%$ is lehet [13]. Más közlemények a nem VP-eredetű PF gyakoriságát 20-32\% között határozzák meg. A nem VP-eredetű pitvarfibrilláló betegek csoportjában a leggyakoribb ectopiás ingerképző góc a vena cava superior (VCS, 26-40\%), valamint a bal pitvar területe (17,5-42\%-ban), a leggyakrabban a hátsó szabad fal. Emellett a crista terminalis (5-15\%), a vena obliqua atrii sinistri (Marshall-ligamentum [LOM], 5-15\%), a septum interatriale $(1,5-11 \%)$, valamint az ostium sinus coronarii $(1-7 \%)$ szerepét is leírták a nem VP-eredetú PF vonatkozásában [14-17].

Az elektroanatómiai térképezések arra utalnak, hogy a nem VP-lokalizációjú triggerek jól meghatározott anatómiai régiókba (alsó mitralis gyưrü, bal pitvar hátsó fala, interatrialis septum [fossa ovalis és annak limbusa], crista terminalis, Eustach-billentyú, sinus coronarius [SC], VCS, bal fülcse, perzisztáló bal VCS, LOM) tömörülnek (2. ábra). E területeken olyan szívizomrostok vannak jelen, amelyek fokozott automácia, triggerelt aktivitás és lokális microreentrykörök együttes hatása következtében arrhythmogen aktivitással bírhatnak [18].

Kugler és mtsai Purkinje-rost morfológiájú, glikogénben gazdag szívizomrostokat figyeltek meg a VP, a VCS, valamint a SC körüli myocardium területén. A szerzők ezekben a régiókban a szív ingerképző és ingerületvezető rendszerében a magas expressziót mutató connexin-45 fehérje kifejezett pozitivitását tapasztalták, amely az extracardialis myocardium lehetséges ingerképző/ingerületvezető természetére utalhat [19].

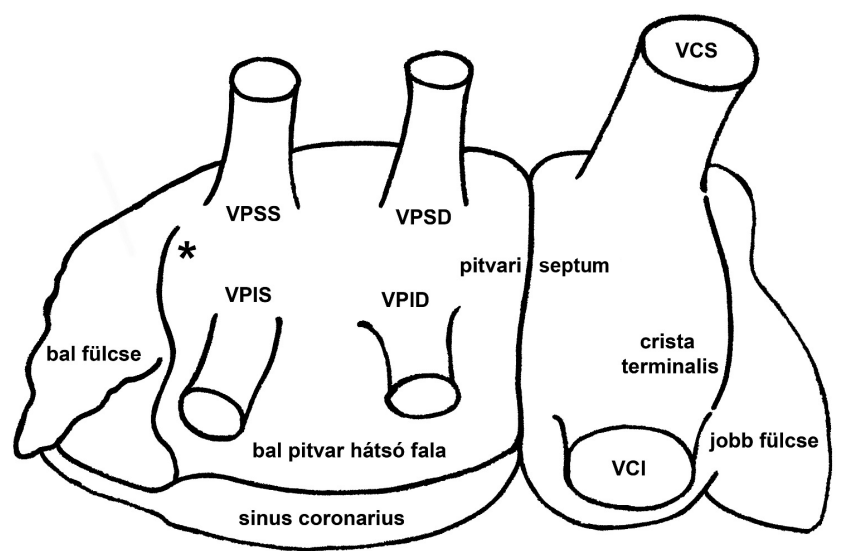

2. ábra Fokális triggerek kiindulási helyeként azonosított jobb és bal pitvari régiók

Pulmonalisvéna-eredetű triggerek eredete: bal felső (VPSS) és alsó (VPIS), jobb felső (VPSD) és alsó (VPID) tüdővénák. Nem pulmonalisvéna-eredetű bal pitvari triggerek forrásai: Marshallligamentum $(*)$, bal fülcse, a bal pitvar hátsó fala. Jobbpitvareredetű arrhythmogen gócok kiindulási helyei: crista terminalis, jobb fülcse, vena cava superior (VCS) és inferior (VCI). A sinus coronarius, valamint a pitvari septum arrhythmogen tulajdonsága is ismert 


\section{Jobbpitvar-eredetu" triggerek}

A nem VP-eredetû triggerek egyik legjelentősebb forrásaként számon tartott VCS területén az embrionális sinus venosusra jellemző spontán ingerképzésre képes szövet van jelen. A jobb felső VP anatómiai közelsége miatt nehézséget jelenthet az ezen régiókból származó triggerek elkülönítése. Az arrhythmogen fókusz a leggyakrabban szegmentális ablatióval izolálható, amelynek során a góctól proximálisan, annak közvetlen közelében hozzák létre a laesiót. Ritkán előforduló szövődményként a sinuscsomó vagy a nervus phrenicus sérülését, illetve a VCS szúkületét írták le, viszonylag kevés esetben [18].

A crista terminalis eredetû PF-triggerek a legkorábbi aktiváció helyén végzett fokális ablatióval eliminálhatók. Szövődményként a jobb oldali nervus phrenicus sérülése fordulhat elő. Az Eustach-billentyű a crista terminalis alsó folytatása, amely elkülöníti a vena cava inferior (VCI) szájadékát a SC-tól. Egy macskán végzett tanulmány [20] pacemakersejtek jelenlétét írta le az Eustachbillentyư területén. A VCI csupán néhány tanulmány esetén bizonyult PF-trigger kiindulási helyének. Ennek magyarázata az, hogy az embrionális fejlődés során a VCI atrialisatiója csupán részlegesen következik be. Azonosított góc esetén fokális ablatio végzendő [18].

Alkalmanként a jobb fülcse lateralis részéről, valamint a tricuspidalis gyưrű területéről eredő triggerek is azonosításra kerülnek [18].

\section{Balpitvar-eredetü triggerek}

A bal pitvar hátsó fala embrionális, anatómiai és elektrofiziológiai szempontból a VP-ok folytatásának tekinthető, ezáltal kifejezett arrhythmogen tulajdonsággal bír. A hátsó fal elektromos izolációja a széles antralis VP-izolációs vonalaknak a bal pitvar tetején (roof) és alján (floor) létrehozott vonalszerű laesiókkal történő összekötésével végezhető. Az eljárás során ügyelni kell arra, hogy a rádiófrekvenciás energia leadása során ne károsodjon a közelben elhelyezkedő oesophagus [18].

A SC pitvari szívizommal behüvelyezett szakasza 3-5,5 cm hosszúságú. Ez a szakasz PF-triggerként, illetve reentrykörök részeként egyaránt szolgálhat. A LOM a bal VCS anatómiai maradványa, és a Vieussens-billentyü szintjében nyílik a SC-ba. A SC-eredetû triggerek fokális ablatióval vagy a SC teljes izolációja révén eliminálhatók. A SC izolációja az endocardialis (bal pitvar), valamint az epicardialis felszín (SC belfelszíne) felől egyaránt elvégezhető [18].

Az interatrialis septum, különösen a fossa ovalis/limbus, továbbá a mitralis gyưrû területén azonosított PFtriggerek eliminálása fokális ablatióval lehetséges [18].

A bal fülcse szájadékának hátsó részéről eredő triggerek esetenként valójában a bal oldali VP-ok vagy a LOM területéról származnak. Valódi bal fülcsei trigger azonosítása esetén a fülcse mechanikus funkciózavarának kivédése céljából fokális ablatio végzendő [18].
A LOM-ból származó triggerek azonosítása a SC-on keresztül történő kanülálással lehetséges. Trigger azonosítása esetén endocardialis úton (a bal pitvar felől) végzett elektromos izoláció javasolt. Ritkán szükséges a SCon keresztül végzett direkt kanülálás vagy etanol LOM-ba injektálása az izoláció komplettálásához. Az esetenként perzisztáló bal VCS, amely a LOM embrionális megfelelője, csakugyan PF-triggerként szolgálhat. A bal VCS a bal fülcse és a bal oldali VP-ok között helyezkedik el, és közvetlen kapcsolatban áll a SC-val. A típusos esetben kitágult SC-on keresztül a véna retrográd úton érhető el $[18,21]$.

\section{Elektrofiziológiai mechanizmusok}

Valószínú, hogy a PF elindításáért VP-eredetű triggerek felelnek [7], a ritmuszavar fenntartásának mechanizmusai azonban nem ismertek pontosan. Az elmúlt években több ezzel kapcsolatos elmélet látott napvilágot. Elektroanatómiai térképezésre alapuló feltételezések felvetették annak lehetőségét, hogy az ectopiás fókuszokon kívül egyéb mechanizmusok is szerepet játszanak a $\mathrm{PF}$ kiváltásában és fenntartásában [5].

Kimutatták, hogy PF során a pitvarokban olyan reentrykörökkel jellemezhető komplex elektromos aktiváció zajlik, amely heterogén elektrofiziológiai szubsztrát jelenlétét feltételezi [5]. A reentry létrejöttének elektroanatómiai alapja, hogy a szívizomrostok egy csoportja nem aktiválódik a kezdeti depolarizációs folyamat hatására, hanem az eredeti impulzus megszűnése előtt válik újra ingerelhetővé. Ezeken a szívizomrostokon keresztül olyan sejtcsoportok juthatnak újra ingerületbe, amelyekben éppen csak lezajlott az eredeti depolarizációs folyamat $[8]$.

\section{„Leading circle reentry”}

A funkcionális reentry legegyszerúbb formája az arrhythmiaszubsztrátum nélküli ingerület-körforgás ( leading circle reentry”). Az ilyen típusú reentrykör nem tartalmaz ingerelhető rést, ezáltal az aktiváció állandóan a kör közepe felé irányul, amelyet így az ingerülethullámok folyamatosan refrakter állapotban tartanak. Ez a refrakter terület olyan funkcionális gátat képez, amely az állandó anatómiai barrierekhez (heg) hasonlóan képes fenntartani a reentrykört $[8,22]$.

\section{„Multiple wavelet” elmélet}

Kitágult pitvar, valamint rövid hullámhosszú (lassú vezetési sebesség/rövid refrakter periódus) reentrykörök esetén lehetôvé válik, hogy egyidejûleg számos reentrykör legyen jelen, amelyek folyamatosan vándorolva egymással találkoznak, és vagy kialszanak, vagy újabb hullámocskákat képeznek [8, 22]. Ez a „multiple wavelet” elmélet, amely szerint a PF annál tartósabb, minél több 
hullámocska van jelen a pitvarokban. Az együttesen előforduló hullámok száma a pitvar összfelületétől és a pitvari impulzus hullámhosszától függ. Mivel kitágult és változó ingerületvezetési tulajdonságokkal bíró pitvarizomzatban több „wavelet” lehet jelen, a pitvartágulat a PF fontos rizikófaktora. A nervus vagus stimulációja a pitvari akciós potenciálnak a teljes szívciklushoz képest történt relatív rövidülése miatt hajlamosít PF-ra. A széles/bifázisos P-hullámok, késői potenciálok, fragmentált pitvari elektrogramok fokozott rizikót jelentenek PF kialakulására [23].

\section{Rotorelmélet}

A rotorok a funkcionális reentry specifikus formái, amelyeknek szerepet tulajdonítanak a PF fenntartásában. A rotorok esetében a hullámfrontnak spirális formája van, és a hullámfront és a hullám vége egy gyújtópontban találkozik. A hullámfront terjedési sebessége a gyújtópont helyén a legalacsonyabb, ezért itt a hullámfront képtelen ingerelni a rotor központjában elhelyezkedő szövetet. Ez a mag a „leading circle” reentryközpontjához hasonlóan funkcionális blokkot képez azzal a különbséggel, hogy a rotor központjában lévő szövet valójában nem refrakter, csupán a gyújtópontban fennálló alacsony vezetési sebesség miatt nehezen ingerelhető. Mindebból az következik, hogy míg a „leading circle” modell esetén a reentrykör a középső terület ingerelhetetlensége miatt állandóan ugyanazon a helyen marad, addig a rotor igen összetett módon képes a térben vándorolni. A rotorok képződéséhez szükséges, hogy a hullámfront valamiféle barrierrel találkozzon, amely lehet strukturális akadály (például heg) vagy valamiféle funkcionális elektromos inhomogenitás, anizotrópia a myocardiumban (például pitvari extraszisztolé hatására). Anizotrópián azt értjük, amikor a szívizomszövet ingerületvezető képessége a szívizomrostok lefutási irányának függvényében jelentős változatosságot mutat. A rotorok esetenként egy meghatározott területen (például VP-ok körüli terület) stabilan rögzülhetnek. A hullámfrontok a myocardium organikus vagy funkcionális inhomogén területeivel interakcióba lépve feltöredezhetnek, majd számos rendezetlen hullámot indukálva kaotikus elektromos aktivitást idézhetnek elő a pitvarokban [22]. A több ezer cikluson keresztül stabil vagy átmeneti, instabil rotorok feltérképezése endocardialis térképezés útján (64 elektródás „basket catheter”), valamint testfelszíni elektródákat (például 252 db) magában foglaló térképezőrendszer révén egyaránt lehetséges [5].

A FIRM- (fokális impulzus- és rotormoduláció) terápia lényege a fokális impulzusok és rotorok katéterablatiós eliminációja. Tartósan pitvarfibrilláló betegek esetében 97\%-ban igazolták rotor vagy fokális impulzusok jelenlétét. Az arrhythmogen forrást $24 \%$-ban jobb pitvari régiókra lokalizálták [11]. Hocini és mtsai arra utalnak, hogy a jobb pitvari ablatióval kiegészített beavatkozásoknak magasabb a sikerarányuk, mint a hagyományos eljárásoknak [24]. Összegzésképpen megállapítható, hogy néhány lokalizált arrhythmogen forrás hatására a pitvarban elektromos dezorganizáció következik be, amely a PF kialakulása szempontjából fokozott rizikót jelent. A FIRM-ablatio révén ezen arrhythmogen források aktivitása megszüntethető vagy mérsékelhető [11].

\section{Komplex frakcionált pitvari elektrogramok}

Perzisztens PF esetén a folyamatos pitvari elektromos aktivitással jellemezhető komplex frakcionált pitvari elektrogramok (CFAE) lehetséges ablatiós célpontként ismertek [25]. A CFAE-k kialakulása számos mechanizmussal magyarázható. A myocardiumnak olyan területein fordulnak elő, ahol a szívizomrostok egymástól elkülönülten, rendezetlenül vannak jelen. Valószínüsíthető, hogy a CFAE-k a pitvaron belüli ingerületvezetés passzív megnyilvánulásai, nem pedig a PF kiváltói [22].

Perzisztens PF esetén a CFAE-ket tartalmazó régiók gyakran a bal pitvar $>50 \%$-ára kiterjednek. Mivel a CFAEhelyek jelentős hányada nem specifikus, indokolttá vált a PF fenntartásában kritikus szereppel bíró területek azonosítása, a CFAE-k morfológiáján alapuló szelektív eljárások kidolgozása [26].

Egy állatmodell tanúsága szerint ibutilid (III-as osztályú antiarrhythmiás szer) alkalmazása mérsékli a pitvari reentrymechanizmusokat, ellenben a PF-t generáló fokális gócok aktivitására nincs hatással. Elképzelhető, hogy az ibutilid alkalmazását követően is fennmaradó CFAE-k területén végzett ablatióval eliminálhatók a PF fenntartásában kritikus szereppel bíró régiók, ami a beavatkozás hatékonyságának és a hosszú távú arrhythmiamentességnek a fokozódását eredményezheti. Egy randomizáltkontrollált, kettős vaktanulmány során perzisztensen pitvarfibrilláló, korábban PVI-n átesett betegek körében a CFAE-ablatiót megelőzően alkalmazott ibutilid hatására a bal pitvar CFAE-t tartalmazó felszíne nagyobb mértékben csökkent ( $8 \%$ versus $1 \%)$, továbbá a PF gyakrabban terminálódott $(71 \%$ versus $56 \%)$, mint placebo adása esetén [26].

\section{A pitvarfibrilláció-ablatio okozta arrbythmogen és egyéb hosszú távú hatások}

Ismert, miszerint a PF-ablatiót követően hetekkel-hónapokkal gyógyszeres terápiára nehezen reagáló, gyakran tartós pitvari tachycardia vagy atípusos pitvari flattern alakulhat ki, amely ismételt katéterablatiós beavatkozás elvégzését teheti szükségessé. Ezek a ritmuszavarok legföképpen kiterjedt pitvari lineáris laesiók képzése esetén lépnek fel, és szubsztrátjukat az inkomplett hegvonalak talaján kifejlődő reentrykörök képezik [27].

Emellett több vizsgálat eredménye utal arra, hogy a kiterjedt ablatio a bal pitvar szisztolés funkciójának károsodásához vezethet, amelynek következtében magasabb thromboemboliás kockázattal kell számolni [28, 29]. 


\section{Epicardialis zsírszövet és pitvari fibrosis}

Az epicardialis zsírszövet a mesenterialis zsírhoz hasonlóan endokrin funkcióval is rendelkezik, továbbá gyulladásos folyamatok helyszínéül szolgálhat. Ezzel szemben a parietalis pericardiumon kívül eső paracardialis zsírszövet vélhetően nem játszik szerepet endokrin és gyulladásos folyamatokban. Az epicardialis zsírszövet által szekretált adipokinek, chemokinek és gyulladásos citokinek szabadon diffundálhatnak az alatta fekvő myocardiumba, annak fibroticus elváltozását előidézve. Obesitas esetén a zsírszövet fibroticus átalakulásra való hajlama fokozott. A subepicardialis zsírszövet arrhythmogen volta a gyulladásos mediátorok, adipokinek által közvetített parakrin hatással, valamint a gyulladás indukálta fibrosis talaján végbemenő remodellációval magyarázható. A myocardiumba infiltráló subepicardialis zsírszövet fibrosisának talaján bekövetkező szerkezeti átalakulás az érintett területeken elektromos disszociációt okoz, az ingerületvezetés lassul és heterogénné válik, unidirekcionális blokkok és reentrykörök képződnek, ezáltal fokozódik a PF kialakulásának és fennmaradásának valószínűsége $[2,3,5,6]$.

A pitvari fibrosis szempontjából rizikótényezőként tekintendő az időskor, a hypertonia, a szívelégtelenség, az obesitas, a szívbillentyú-betegség, az OSAS fennállása, továbbá maga a PF is hajlamosít epicardialis túlsúlyú kötőszövetes elfajulásra a pitvarokban. A fibrosist előidéző folyamatban számos tényező (gyulladáskeltő citokinek, oxidatív stressz, transzformáló növekedési faktor-béta, RAAS, kalciumdependens proteázok, extracelluláris mátrixot szabályozó fehérjék, hypoxia indukálta faktor1-alfa, endothelin-1) szerepet játszik. A fokozott fizikai terhelés vagy gyulladás okozta következményes fibrosis [30] szerepe szintén jelentős.

Haemers és mtsai szívmütéten átesett betegek jobb fülcséből származó szövetmintáin vizsgálták az esetenként jelentősen fibroticus (remodellált) zsíros infiltrátumoknak a PF patomechanizmusában betöltött szerepét. A PF az epicardialis remodelláció szignifikáns klinikai prediktorának bizonyult. CD8+ citotoxikus T-lymphocyták aggregátumait is leírták a subepicardialis zsírszövetben, ami arra utal, hogy a zsíros-kötőszövetes infiltrátumok területén immunreakció is zajlik. Mivel a pitvari zsírszövet fibrosisában számos klinikai tényezőnek szerepe lehet, a szerzők juhoknál gyors pitvari ingerléssel perzisztens PF-t kiváltva is végeztek elemzéseket. Ezt a modellt alkalmazva a PF szöveti szintű hatásai jelentős bal kamrai funkciózavar hiányában vizsgálhatók. A pitvarfibrilláló juhok esetén a zsíros infiltrátumok területén nagyobb arányban voltak jelen lymphocytaaggregátumok, mint a kontrollállatokban [31].

A pitvari fibrosis kiemelt jelentőségére utal, hogy felmerült a „kötőszövetes pitvari szívizom-elfajulás” (FACM) mint önálló fogalom alkalmazása. A pericardialis zsírszövet össztérfogata arányos a PF gyakoriságával és súlyosságával, továbbá az ablatiót követő arrhythmiavisszatérés valószínúségével [3]. A pitvari fibrosisnak mindemellett a kriptogén stroke-ok kialakulásában is szerepet tulajdonítanak. Fokozott pitvari fibrosis esetén gyakrabban észlelhető a bal fülcsében spontán echókontraszt, valamint thrombus [2].

\section{A pitvari fibrosis mértékének jelentösége a katéterablatio sikerességére}

Számos katéterablatiós vizsgálat elemezte a pitvari fibrosis mértékének jelentôségét. A pitvari fibrosis kimutatható szövettani úton, elektrofiziológiai módszerekkel (pitvari feszültségértékek csökkenése), továbbá késői kontraszthalmozásos technikával végzett szív-MRI (DEMRI)-vizsgálattal. A DE-MRI lehetőséget nyújt a pitvari fibrosis noninvazív úton történő mennyiségi meghatározására. Az eljárás lehetôvé teszi a fibroticus és az ép myocardium differenciálását. Meghatározható a fibroticus myocardium teljes pitvarfali térfogathoz viszonyított \%-os mennyisége. A százalékos értékeken alapuló Utahklasszifikáció négyfokozatú skálán jellemzi a pitvari fibrosis kiterjedtségét: I.: < 10\% fibrosis; II.: 10-20\% fibrosis; III.: 20-30\% fibrosis; IV.: $>30 \%$ fibrosis. PF-ban szenvedő populációban a késői kontraszthalmozású területek jellegzetes lokalizációi a bal VP-antrum, továbbá a bal pitvar hátsó és oldalsó fala. Perzisztens PF esetén ezek a régiók, különösen a bal pitvar elülső és hátsó falát illetően, fokozottabb kiterjedést mutatnak. A pitvari fibrosis mértéke, továbbá a legnagyobb fibroticus terület mérete jelentős hatással van az ablatiót követő arrhythmia-visszatérésre. Eszerint magas ablatiós sikerarány várható Utah I. stádiumban, továbbá kisméretű fibroticus területekkel bíró Utah II. és III. stádiumban. Nagyméretü fibroticus régiók, továbbá Utah IV. stádium esetén a sikeres ablatio esélye csekélyebb $[2,5,32]$.

\section{Az ablatiót köpetốen fennmaradó residualis fibrosis szerepe}

A katéterablatio célja krónikus transmuralis laesio létrehozatala. A DE-MRI lehetővé teszi az ablatio során képzett hegek, valamint a residualis fibrosis megítélését. A visszatérő ritmuszavarmentes túlélés igazoltan összefügg a residualis fibrosissal [33]. Amíg a stabil heges laesio az ablatiót követő arrhythmiamentesség szempontjából kedvező, addig progresszív fibrosis esetén a ritmuszavar visszatérése várható [2].

\section{Autonóm idegrendszeri hatások}

Az autonóm idegrendszer aktivációja jelentős elektrofiziológiai változásokat idézhet elő a pitvarokban, pitvari tachyarrhythmiák indukcióját előidézve $[22,34]$.

\section{A szín vegetatín beidegzése}

A szív vegetatív beidegzésében a szíven kívüli (extrinsic), valamint a szíven belüli (intrinsic) ganglionoknak egya- 
ránt jelentős szerepük van. Az intrinsic autonóm idegrostok föként a pitvarokban, különösképpen a bal pitvarVP junkció közelében, az epicardium alatt találhatók. Az itt elhelyezkedő ganglionplexusoknak közvetítő szerepük van az autonóm stimulusok arrhythmogenesisében. A ganglionsejtek mintegy 30\%-a adrenerg és kolinerg immunfenotípussal egyaránt rendelkezik, emiatt a szimpatikus és paraszimpatikus idegrostok szelektív rádiófrekvenciás ablatiója nehézségekbe ütközhet $[22,34]$.

\section{Autonóm hatások sejtszintü mechanizmusai}

Az autonóm pitvari remodelláció magában foglalja az extrinsic (szimpatikus és paraszimpatikus), valamint a komplex idegi hálózatot képező intrinsic ganglionok szintjén történő funkcionális változásokat. A béta-adrenerg, illetve a kolinerg tónus fokozódása, a katecholaminerg és a vagustónus egyensúlyának megváltozása egyaránt PF-t indukálhat [5]. A fokozott adrenerg tónus a fokális ectopiás gócok automáciájának fokozása, illetve kalciumdependens triggerelt aktivitás növelése révén válthat ki ritmuszavart, míg a kifejezett vagustónus az acetilkolindependens káliumáramot indukálva a pitvari refrakter periódus csökkenése révén reentrykörök kialakulásának kedvez. A vagustónus fokozódása során a refrakteritás csökkenése jelentős regionális különbségeket mutat, ami hozzájárul a fokozott vagustónus PF-t indukáló hatásához. A PF tartóssá válásában kiemelt szerep jut a strukturális remodellációnak. A béta-adrenerg stimuláció által kiváltott fokozott kalciumáram géntranszkripciós változásokat indukálva szívizomsejt-hypertrophiát és fibrosist idéz elő [34].

\section{Társbetegségek és életmódbeli tényezök szerepe az autonóm idegrendszeri hatásokon keresztül}

$\mathrm{Az}$ autonóm idegrendszeri hatásokat különféle társbetegségek befolyásolják [22]. Egyes kórállapotok (például myocardialis infarctus) esetén az autonóm idegrostok aktivitása fokozódhat, ami pitvari és kamrai arrhythmiák fellépését idézheti elő. Jellemző a pitvari szimpatikus innerváció fokozódása magas frekvenciájú tartós PF kialakulásában [34].

Az utóbbi években több vizsgálat foglalkozott a fizikai aktivitás és a PF összefüggésével. A mérsékelt testedzés kedvező hatásával ellentétben az állóképességi sportok versenyszintű üzése esetén a PF hajlama magasabbnak bizonyult. Noha az időskorban végzett rendszeres séta a ritmuszavar kialakulása szempontjából minden bizonynyal kedvező, napi szinten végzett futás esetén fiatal férfiaknál a PF gyakorisága magasabbnak bizonyult. Nielsen és mtsai metaanalízise hasonló eredményeket igazolt. Eszerint a hosszú távú, intenzív sporttevékenység, továbbá a fizikai aktivitás teljes hiánya egyaránt fokozza a $P F$ rizikóját, míg a rendszeres mérsékelt testmozgás a $\mathrm{PF}$ szempontjából kedvező hatással bírhat. A PF kialakulása szempontjából kedvezőtlen fizikai aktivitás pontos mértéke ugyanakkor igen nehezen határozható meg [35, 36]. Egy hazai közlemény tanúsága szerint heti 3-5 órányi testmozgás számos pozitív egészségi előnye mellett nem növeli a PF kockázatát [37].

A fizikai aktivitásnak az általános egészségi állapotra és a cardiovascularis rendszerre, így a PF kialakulására kifejtett hatásában számos patofiziológiai tényező játszik szerepet. Az aerob testedzés során a paraszimpatikus tónus, a baroreceptorok érzékenysége, valamint a szívizomrostok kolinerg érzékenysége fokozódik, ami együttesen a pitvari refrakteritás csökkenését előidézve PF-t indukálhat. Újabban az epidemiológiai adatokon kívül [38] humán biokémiai és MRI-vizsgálatokkal is igazolták [39, 40], hogy az elhúzódó bal és jobb pitvari fizikai terhelés és a következményes emelkedett pulmonalis nyomás élsportolókban fokozott pitvari fibrosist is okoz, amely a PF kiváltásában is szerepet játszik. A nem extrém sportterhelés (testedzés) során megnyilvánuló paraszimpatikus tónusfokozódás ugyanakkor a PF szempontjából protektív hatással is bírhat $[5,34]$. Ezzel szemben, amint Nielsen és mtsai kifejtik, a mozgásszegény életmód elhízáshoz, diabeteshez, hypertoniához és coronariabetegséghez vezethet, valamint a szívfrekvencia növekedését okozhatja, ezáltal fokozva a PF előfordulási gyakoriságát. A rendszeres mérsékelt fizikai terhelés a felsorolt tényezők mérséklésével csökkenti a PF kockázatát [36].

\section{Az autonóm idegrendszeren keresztül ható terápiás lehetöségek}

Az autonóm idegrendszer modulációja lehetőséget nyújt a pitvari remodelláció folyamatának befolyásolására. Az autonóm idegrendszer túlzott aktivitása gátolható gyógyszerek révén, eszközös úton, emellett a rendszeres sporttevékenység is kedvező hatású. Az antiarrhythmiás gyógyszeres terápiák jelentős része hatással van az autonóm idegrendszerre. A béta-blokkolók széles körben alkalmazott, a szimpatikus idegi aktivitást gátló gyógyszerek, amelyek az elektromos cardioversio után visszatérő, valamint a posztoperatív PF megelőzése szempontjából is kedvező hatásúnak bizonyultak. Az elsőként alkalmazandó gyógyszeres kezelés mellett az alábbiakban ismertetett eszközös beavatkozások is a neuromodulációs terápiás lehetőségek közé sorolandók. Mivel a szívre ható autonóm idegi struktúrák egymással jelentős mértékben együttmúködnek, a neuromodulációs terápiák során egy adott területet célzó beavatkozások egyéb struktúrákra is hatással lehetnek. A szimpatikus denerváció hosszú távú hatásai jelenleg nem ismertek $[5,34]$.

A szimpatikus beidegzés gátlása elérhető átmeneti úton a nervus vagus cervicalis szakaszának stimulációjával, vagy végleges módon, a ganglion stellatum denervációjával. A baroreflex eszközös aktiválása a sinus caroticus direkt úton történő stimulálása révén lehetséges. A nervus vagus stimulációhoz hasonlóan ez az eljárás is jelentősen csökkenti a szimpatikus idegi aktivitást. Enyhe 
fokú stimuláció során a pitvari refrakter periódus nagyfokú, kedvezötlen csökkenése nem következik be. A szomatikus idegek transzkután stimulációja (például a tragus területén) autonómreflex-válaszokat eredményezhet [34].

A PVI során gyakran a VP-ok körüli ganglionplexus részleges ablatiója is bekövetkezik. Ez járulékosan történik, de ezenfelül vizsgálták a célzott ganglionablatio hatását is, változó eredménnyel. Egyes vizsgálatok tanúsága szerint ganglionablatióval kiegészített PVI esetén magasabb sikerarány várható, mint kizárólagos PVI-t követően. Más tanulmányok ugyanakkor arról tesznek említést, hogy a terápiás célú ganglionablatiónak olykor paradox hatása is lehet $[5,22,34]$.

Az endovascularis úton végzett renalis szimpatikus denerváció gyógyszeres terápiára nem reagáló hypertensio esetén kísérleti kezelési módszer. Az eljárás a szimpatikus idegi aktivitás csökkentése révén a PF neuromodulációs terápiájában is használatos lehet. A renalis szimpatikus denerváció közvetlen hatást gyakorolhat a pitvari szubsztrátra. A beavatkozás következtében a RAAS aktivitása csökken, a pitvari fibrosis, gyulladás, apoptózis mérséklődik [5, 34]. Az atrioventricularis csomóra ható paraszimpatikus idegek stiumulálása a gyógyszeres kezelésre nem reagáló magas kamrafrekvenciájú PF frekvenciakontroll-terápiájának lehetséges invazív megoldása lehet $[41,42]$.

\section{Fokozott alvadékonyság}

A PF fennállása fokozott alvadékonysággal járó állapot. A fokozott alvadékonyság szintén arrhythmogen hatású. A PF idején fennálló ischaemia aktiválja az alvadási faktorokat, amelyek proteáz aktiválta receptorokat (PARs) stimulálva szívizomsejt-hypertrophiát, gyulladásos reakciót, valamint fibroblastaktiváció talaján pitvari fibrosist idéznek elő. A fokozott alvadékonyság által aktivált folyamatok a pitvarok strukturális remodellációját előidézve megzavarják a szívizomrostok közötti ingerületvezetést, és ezáltal a PF szubsztrátjául szolgálnak [5, 43].

Patkányból izolált pitvari fibroblastokban thrombin hatására a fibrosist és gyulladást indukáló folyamatok fokozódását figyelték meg. A thrombint gátló dabigatrán mérsékelte ezeket a hatásokat. Thrombomodulinmutáció miatt fokozott alvadékonyságra hajlamos fenotípusú transzgenikus egerek esetén könnyebben lehetett PFepizódokat indukálni, és azok tartósabb ideig álltak fenn, mint a vad fenotípusban. Mindezek az adatok arra utalnak, hogy a fokozott alvadékonysággal járó állapotoknak szerepük lehet a PF-szubsztrát kialakulásában. A NOAC-ok eredményesen gátolják a pitvari fibroticus folyamatokat és a PF szubsztrátjának kialakulását, ezáltal késleltethetik a PF progresszióját, továbbá a pitvari thrombusképződést és a következményes stroke kialakulását [43].

\section{Genetikai tényezők}

A „Framingham Heart Study” tanulmány igazolta, hogy PF-ban szenvedő egyének leszármazottainak egyéb PFra hajlamosító kórállapotok fennállásától függetlenül fokozódott a PF-rizikójuk [44]. Egyes nukleotidpolimorfizmusok (például a 4q25-ös kromoszómalocuson) feltételezhetően hajlamosítanak PF kialakulására. A 4q25-ös locus a PITX2-es (paired-like homeodomain transzkripciós faktor-2) géntől nem messze helyezkedik el, amelynek az embrionális szívfejlődés során kulcsszerepe van a VP körüli myocardiumhüvely kialakulásában [45].

Az elmúlt években számos feszültségfüggő nátrium- és káliumcsatornát érintő mutációt, illetve variációt azonosítottak a PF hátterében. A PF-hoz társuló káliumcsatornavariánsok többsége a csatorna fokozott múködését idézi elö, aminek következtében a pitvarban a repolarizáció hamarabb következik be, az akciós potenciál időtartama és a refrakter periódus rövidül, s ez reentrykörök kialakulásának kedvez. A káliumcsatornák funkcióvesztő mutációja a pitvari akciós potenciál időtartamának megnyúlásán keresztül, korai utódepolarizációt okozva vált ki PF-t. A feszültségfüggő nátriumcsatornák funkciónyerő, -vesztő variációi egyaránt arrhythmogen szubsztrátot eredményeznek. A connexin 40 gap junction proteint kódoló gén mutációja a pitvarokban az ingerületvezetési sebesség csökkenéséhez vezet, ami reentrykörök képződésének kedvez. Jelátviteli faktoroknak és egyéb (lamin, natriureticus peptid prekurzor) molekuláknak a variációit is azonosították a PF hátterében $[46,47]$.

A pitvari miozinkönnyưláncot kódoló MYL4-génen belüli deletiónak a recesszíven öröklődő, korai kezdetű PF patogenezisében tulajdonítanak szerepet [48].

\section{A pitvarfibrilláció szerepe a pitvarfibrilláció patomechanizmusában}

Egy tanulmány tanúsága szerint társbetegségekkel nem rendelkező, paroxismalisan pitvarfibrilláló betegeknél átlagosan 15 év alatt 18\%-ban fejlődik ki tartós PF [49]. Rövidebb ideig tartó paroxismusok esetén kisebb, míg hosszabb fennállás esetén nagyobb gyakorisággal alakul ki krónikus ritmuszavar [50]. Kémiai vagy elektromos cardioversio nagyobb sikeraránnyal végezhető rövid ideje fennálló PF esetén. Ezek a megfigyelések arra utalnak, hogy a PF a háttérben álló tényezőktől függetlenül, önmagában progresszív betegség, és lefolyása során olyan elektrofiziológiai és szerkezeti elváltozásokat okoz, amelyek elősegítik újabb PF-epizódok kialakulását, valamint a ritmuszavar állandósulását [23].

Wijffels és mtsai (1995) 12 kecske pitvari epicardiumára számos elektródát varrtak, majd 2-3 hét múlva egy külsőleg csatlakoztatott pacemaker segítségével mesterséges úton PF-t idéztek elő. Amíg a folyamat elején, sinusritmus fennállása mellett, az indukált PF-epizódok csupán néhány másodpercig tartottak, és jellemzően 
spontán szűntek, addig a ritmuszavar hosszan tartó mesterséges fenntartása a PF időtartamának progresszív növekedését okozta, míg végül a ritmuszavar tartóssá vált, és többé nem szűnt meg magától. 24 órán keresztül fenntartott PF hatására a PF indukálhatósága 24\%-ról 76\%-ra fokozódott. A pitvari effektív refrakter periódus az első 24 órában pitvarszerte jelentősen csökkent. A krónikus PF kialakulásával párhuzamosan a pitvari elektrogramok morfológiája is megváltozott, az amplitúdó csökkenése mellett nagyfokú fragmentáció és az izoelektromos szakaszok megszûnése vált jellemzővé [23].

A tanulmány során azt is megfigyelték, hogy hosszan fennálló PF esetén a pitvari refrakter periódus a fiziológiás reakciótól eltérően nem csökken az ingerlési frekvencia növelésének hatására. Ennek jelentőségét az adja, hogy amennyiben cardioversiót követően a jelentős frekvenciacsökkenést nem kíséri a refrakter periódus kellő megnyúlása, a helyreállított sinusritmus ideje alatt a pitvarban kritikusan rövid marad a refrakter periódus, ami a PF korai újraindulását okozhatja egy pitvari extraszisztolé hatására [23].

A tanulmány során tapasztalt pitvari refrakteritás csökkenése és az ezzel párhuzamosan rövidülő fibrillációs ciklushossz mellett vélhetően egyéb tényezők (a pitvarok tágulata, a pitvaron belüli ingerületvezetési sebesség általános csökkenése, helyi ingerületvezetési blokkok) is szerepet játszhatnak a krónikus elektrofiziológiai adaptációban és ezáltal a PF tartóssá válásában [23].

A Wijffels és mtsai (1995) által közölt „atrial fibrillation begets atrial fibrillation” (a PF újranemzi önmagát) elmélet értelmében tehát a PF talaján olyan elektrofiziológiai változások következnek be, amelyek az effektív refrakter periódus csökkenése révén a ritmuszavar további fennmaradását okozzák [23]. Hosszú ideje fennálló PF esetén a bal pitvarban remodellációs folyamatok következnek be, amelyek elektrofiziológiai (bal pitvari szignálok alacsony feszültségértéke), valamint képalkotó (MRI-) módszerekkel is igazolhatók. Fontos tényező, hogy a PF folyamatos fennállásának időtartamával arányosan a pitvari elektromos aktivitás egyre komplexebbé válik, a PF indukálta pitvari remodelláció pedig a ritmuszavar késői stádiumában egyre inkább elősegíti az újabb epizódok kialakulását [4]. Emellett nyilvánvalóvá vált, hogy a PF strukturális változásokhoz (pitvari fibrosis, bal pitvari dilatáció) is vezet, ezáltal is elősegítve a ritmuszavar állandósulását. A pitvari remodelláció tehát kiváltja, majd fenntartja a ritmuszavart, ami önrontó kör módjára felgyorsítja a remodelláció folyamatát. Fontos tényező azonban, hogy a PF klinikai megjelenése és lefolyása egyénenként igen változatos, továbbá az említett strukturális remodelláció nem pitvarfibrilláló betegek esetében is jelen lehet [2]. A sinusritmus fenntartásának elönyeként tartják számon a PF indukálta pitvari károsodás mérséklődését, az elektromos és strukturális remodelláció esetleges visszafordítását (reverz remodelláció).

\section{A társbetegségek szerepe}

Az elmúlt évtizedekben számos rizikófaktort azonosítottak a PF kialakulásában, valamint a PF-epizódok visszatérésének hátterében, úgymint idős életkor, hypertonia, obesitas, szívelégtelenség, krónikus vesebetegség, OSAS, az aortabillentyű meszesedése, dohányzás, intenzív sporttevékenység, a testedzés hiánya, PF-ban eltöltött idő, genetikai faktorok, pericardialis zsírszövet [4, 5]. Egy nemrégiben megjelent közlemény adatai szerint a praehypertensio, valamint az emelkedett éhomi vércukorszint normál testsúlyú egyének esetén is hajlamosít új keletû PF kialakulására [51]. Hosszú ideje fennálló PF, valamint cardiovascularis társbetegségek jelenléte esetén a bal pitvarban remodellációs folyamatok következnek be [4]. Az akut myocardialis infarctust követő időszakban 6-21\% gyakorisággal lép fel PF [52].

\section{Az obesitas jelentôsége a pitvarfibrilláció patogenezisében}

A Danish Diet, Cancer, and Health Study tanulmány kimutatta, hogy a testtömegindex (BMI) növekedésével párhuzamosan a véletlenül felfedezett PF kockázata fokozódott [53].

Nalliah és mtsai részletesen ismertetik az elhízásnak a PF patogenezisében feltételezett szerepét. Az elhízás hemodinamikai, szerkezeti és elektromos múködészavart okoz a pitvarokban, a pitvar fibroticus átalakulása jellemző, ezáltal fokozza a PF kialakulásának és progressziójának rizikóját. Obesitas esetén nemritkán alakul ki diasztolés diszfunkció, amely mellett a PF gyakrabban jelentkezik perzisztens formában, súlyosabb tünetekkel. Állatmodell esetén azt tapasztalták, hogy testsúlygyarapodás hatására pitvari megnagyobbodással, kamrai hypertrophiával, pericardialis zsírdepozícióval, heterogén ingerületvezetéssel jellemezhető progresszív remodelláció következik be, amelynek talaján a PF gyakoribbá válik. A pericardialis zsír tartós obesitas esetén leginkább a bal pitvar hátsó falát infiltrálja [3].

\section{Az obstruktiv alvási apnoe szerepe a pitvarfibrilláció patomechanizmusában}

Az OSAS jellemzője a felső légutak alvás közbeni átmeneti kollapszusa, amely hypoxiát, hypercapniát, kóros mellűri nyomásváltozást, valamint autonóm idegrendszeri túlmúködést okoz. Ezek a patofiziológiai mechanizmusok kölcsönös egymásra hatással növelhetik a PF rizikóját. Ráadásul OSAS esetén fokozott cardialis remodellációt és szisztémás gyulladást igazoltak, amely tényezőknek szintén szerepük lehet a PF genezisében és fenntartásában [54]. 


\section{A társbetegségek kezelésének szerepe a pitvarfibrilláció terápiájában}

A rendellenes pitvari remodellációért felelős kockázati tényezők jelentôs csökkentését célzó terápia lehetővé teszi a PF-szubsztrát mérséklését. Intenzív testsúlycsökkentés, valamint az egyéb társuló rizikófaktorok (csökkent ejekciós frakciójú szívelégtelenség, revascularisatiót igénylő ischaemiás szívbetegség, mitralisbillentyü-betegség) evidenciákon alapuló, hatékony kezelése reverz szubsztrátremodellációt elóidézve a PF-ban eltöltött idő csökkenését és az ablatio sikerarányának javulását eredményezheti. Pitvarfibrilláló betegeknél, eredményes billentyü- vagy coronariamútét után érdemes a sinusritmus visszaállítását megpróbálni. Kimutatták, hogy a pitvari fibroticus folyamatok mérsékelhetők a RAAS és a HMGCoA-reduktáz gátlása (angiotenzinkonvertálóenzimgátlók, angiotenzinreceptor-blokkolók, statinok), továbbá többszörösen telítetlen zsírsavak alkalmazása révén. A csökkent ejekciós frakciójú szívelégtelenség gyógyszeres terápiája (angiotenzinkonvertálóenzim-gátlók, béta-blokkolók, mineralokortikoidreceptor-antagonisták) mellett a központi szimpatikus tónusra ható moxonidinnek is szerepet tulajdonítanak a PF prevenciója szempontjából [3-5].

\section{Következtetések}

A PVI a PF általánosan elfogadott, széles körben alkalmazott terápiás módszere, amelynek sikeraránya azonban, különösen perzisztensen pitvarfibrilláló egyének esetén, a javuló eredmények ellenére sem emelhetó egy bizonyos határ fölé. Noha az ablatiót követő arrhythmiavisszatérés oka a korai időszakban a VP-ok szájadékánál képzett heg vezetóképességének a helyreállása, később a PF-szubsztrát progrediálása miatt újul ki a ritmuszavar. PF esetén a terápiás siker növelése érdekében tehát olyan kezelési stratégiákra is szükség lehet, amelyek a PF patomechanizmusában szerepet játszó számos lehetséges tényezőt figyelembe véve célozzák meg a ritmuszavar eliminálását. A PF fenntartásában jelentőséggel bíró, újonnan felismert faktorok (pitvari epicardialis zsírszövet és fibrosis, nem VP-eredetú arrhythmogen gócok, rotorok, autonóm idegrendszeri hatások) mértéke nagyfokú egyéni változatosságot mutat. Ezeknek a tényező́knek a vizsgálatára egyre több noninvazív módszer (CT, DE-MRI, testfelszíni térképezés) áll rendelkezésre. Az arrhythmogen trigger- és szubsztrátmechanizmusok azonosítása olyan egyénre szabott terápiás módszerek (fibrosis mérséklése a RAAS gátlásán keresztül, hegek homogenizálása, rotorok és nem VP-eredetú fókuszok ablatiója, neuromoduláció) kidolgozását teszik lehetővé, amelyek alkalmazása a jelenleg evidenciákon alapuló VPablatio hosszú távú eredményességére is kedvező hatással lehet. Mindezek mellett, a tartós terápiás siker érdekében, elengedhetetlen a fennálló kockázati tényező́k hatékony csökkentése, illetve kezelése.
Anyagi támogatás: A közlemény megírása, illetve a kapcsolódó kutatómunka anyagi támogatásban nem részesült.

Szerzői munkamegosztás: K. Sz.: Szakirodalmi adatok gyújtése, a kézirat piszkozatának megírása, ábrák elkészítése. D. G.: Szakirodalmi adatok gyújtése, a kézirat piszkozatának megírása. P. I.: A dolgozat koncepciójának kialakítása, a megfogalmazottak pontosítása. A cikk végleges változatát valamennyi szerző elolvasta és jóváhagyta.

Érdekeltségek: A szerzőknek nincsenek érdekeltségeik.

\section{Irodalom}

[1] Chugh SS, Havmoeller R, Narayanan K, et al. Worldwide epidemiology of atrial fibrillation: a Global Burden of Disease 2010 Study. Circulation 2014; 129: 837-847.

[2] Gal P, Marrouche NF. Magnetic resonance imaging of atrial fibrosis: redefining atrial fibrillation to a syndrome. Eur Heart J. 2017; 38: 14-19.

[3] Nalliah CJ, Sanders P, Kottkamp H, et al. The role of obesity in atrial fibrillation. Eur Heart J. 2016; 37: 1565-1572.

[4] Kirchhof P, Calkins H. Catheter ablation in patients with persistent atrial fibrillation. Eur Heart J. 2017; 38: 20-26.

[5] Lau DH, Schotten U, Mahajan R, et al. Novel mechanisms in the pathogenesis of atrial fibrillation: practical applications. Eur Heart J. 2016; 37: 1573-1581.

[6] Auer J. Fat: an emberging player in the field of atrial fibrillation. Eur Heart J. 2017; 38: 62-65.

[7] Haïssaguerre M, Jaïs P, Shah DC, et al. Spontaneous initiation of atrial fibrillation by ectopic beats originating in the pulmonary veins. N Engl J Med. 1998; 339: 659-666.

[8] Rubart M, Zipes DP. Genesis of cardiac arrhythmias: Electrophysiological considerations. In: Zipes DP, Libby P, Bonow RO, et al. (eds.) Braunwald's heart disease. A textbook of cardiovascular medicine. Elsevier Saunders, Philadelphia, PA, 2005; pp. $653-688$

[9] Cappato R, Calkins H, Chen SA, et al. Updated worldwide survey on the methods, efficacy, and safety of catheter ablation for human atrial fibrillation. Circ Arrhythm Electrophysiol. 2010; 3: 32-38.

[10] Kuck KH, Brugada J, Fürnkranz A, et al. Cryoballoon or radiofrequency ablation for paroxysmal atrial fibrillation. $\mathrm{N}$ Engl J Med. 2016; 374: 2235-2245.

[11] Narayan SM, Krummen DE, Shivkumar K, et al. Treatment of atrial fibrillation by the ablation of localized sources. J Am Coll Cardiol. 2012; 60: 628-636.

[12] Santangeli P, Zado ES, Hutchinson MD, et al. Prevalence and distribution of focal triggers in persistent and long-standing persistent atrial fibrillation. Heart Rhythm 2016; 13: 374-382.

[13] Di Biase L, Burkhardt JD, Mohanty P, et al. Left atrial appendage: an underrecognized trigger site of atrial fibrillation. Circulation 2010; 122: 109-118.

[14] Lin WS, Tai CT, Hsieh MH, et al. Catheter ablation of paroxysmal atrial fibrillation initiated by non-pulmonary vein ectopy. Circulation 2003; 107: 3176-3183.

[15] Lee SH, Tai CT, Hsieh MH, et al. Predictors of non-pulmonary vein ectopic beats initiating paroxysmal atrial fibrillation: Implication for catheter ablation. J Am Coll Cardiol. 2005; 46: 10541059.

[16] Yamaguchi T, Tsuchiya T, Miyamoto K, et al. Characterization of non-pulmonary vein foci with an EnSite array in patients with paroxysmal atrial fibrillation. Europace 2010; 12: 1698-1706.

[17] Chang HY, Lo LW, Lin YJ, et al. Long-term outcome of catheter ablation in patients with atrial fibrillation originating from non- 
pulmonary vein ectopy. J Cardiovasc Electrophysiol. 2013; 24: $250-258$.

[18] Santangeli P, Marchlinski FE. Techniques for the provocation, localization, and ablation of non-pulmonary vein triggers for atrial fibrillation. Heart Rhythm 2017; 14: 1087-1096.

[19] Kugler Sz, Nagy N, Rácz G, et al. Presence of cardiomyocytes exhibiting Purkinje-type morphology and prominent connexin 45 immunoreactivity in the myocardial sleeves of cardiac veins. Heart Rhythm 2018; 15: 258-264.

[20] Rubenstein DS, Fox LM, McNulty JA, et al. Electrophysiology and ultrastructure of Eustachian ridge from cat right atrium: a comparison with SA node. J Mol Cell Cardiol. 1987; 19: 965976.

[21] Ozcan EE, Széplaki G, Merkely B, et al. Isolation of persistent left superior vena cava during atrial fibrillation ablation. Indian Pacing Electrophysiol J. 2015; 15: 130-132.

[22] Waks JW, Josephson ME. Mechanisms of atrial fibrillation Reentry, rotors and reality. Arrhythm Electrophysiol Rev. 2014; 3: $90-100$.

[23] Wijffels MC, Kirchhof CJ, Dorland R, et al. Atrial fibrillation begets atrial fibrillation. A study in awake chronically instrumented goats. Circulation 1995; 92: 1954-1968.

[24] Hocini M, Nault I, Wright M, et al. Disparate evolution of right and left atrial rate during ablation of long-lasting persistent atrial fibrillation. J Am Coll Cardiol. 2010; 55: 1007-1016.

[25] Nademanee K, McKenzie J, Kosar E, et al. A new approach for catheter ablation of atrial fibrillation: mapping of the electrophysiologic substrate. J Am Coll Cardiol. 2004; 43: 2044-2053.

[26] Singh SM, d'Avila A, Kim YH, et al. The modified stepwise ablation guided by low-dose ibutilide in chronic atrial fibrillation trial (the MAGIC-AF study). Eur Heart J. 2016; 37: 16141621.

[27] Sághy L, Tutuianu C, Szilágyi J. Atrial tachycardias following atrial fibrillation ablation. Curr Cardiol Rev. 2015; 11: 149-156.

[28] Wylie JV Jr, Peters DC, Essebag V, et al. Left atrial function and scar after catheter ablation of atrial fibrillation. Heart Rhythm 2008; 5: 656-662.

[29] Nori D, Raff G, Gupta V, et al. Cardiac magnetic resonance imaging assessment of regional and global left atrial function before and after catheter ablation for atrial fibrillation. J Interv Card Electrophysiol. 2009; 26: 109-117.

[30] Platonov PG. Atrial fibrosis: an obligatory component of arrhythmia mechanisms in atrial fibrillation? J Geriatr Cardiol. 2017; 14: 233-237.

[31] Haemers P, Hamdi H, Guedj K, et al. Atrial fibrillation is associated with the fibrotic remodelling of adipose tissue in the subepicardium of human and sheep atria. Eur Heart J. 2017; 38: 5361.

[32] Higuchi K, Cates J, Gardner G, et al. The spatial distribution of late gadolinium enhancement of left atrial magnetic resonance imaging in patients with atrial fibrillation. JACC Clin Electrophysiol. 2018; 4: 49-58.

[33] Akoum N, Wilber D, Hindricks G, et al. MRI assessment of ablation-induced scarring in atrial fibrillation: analysis from the DECAAF study. J Cardiovasc Electrophysiol. 2015; 26: 473480.

[34] Chen PS, Chen LS, Fishbein MC, et al. Role of the autonomic nervous system in atrial fibrillation. Pathophysiology and therapy. Circ Res. 2014; 114: 1500-1515.

[35] La Gerche A, Schmied CM. Atrial fibrillation in athletes and the interplay between exercise and health. Eur Heart J. 2013; 34: 3599-3602.

[36] Nielsen JR, Wachtell K, Abdulla J. The relationship between physical activity and risk of atrial fibrillation - A systematic review and meta-analysis. J Atr Fibrillation 2013; 5: 789.
[37] Apor P. Atrial fibrillation and physical activity. [Pitvarfibrilláció és a fizikai aktivitás.] Orv Hetil. 2013; 154: 503-509. [Hungarian]

[38] Mokhayeri Y, Nashemi-Nazari SS, Mansournia MA, et al. The association between physical activity and atrial fibrillation applying the Heaviside function in survival analysis: the Multi-Ethnic Study of Atherosclerosis. Epidemiol Health 2017; 39: e2017024.

[39] Turagam MK, Flaker GC, Velagapudi P, et al. Atrial fibrillation in athletes: pathophysiology, clinical presentation, evaluation and management. J Atr Fibrillation 2015; 8: 1309.

[40] Wilson M, O'Hanlon R, Prasad S, et al. Diverse patterns of myocardial fibrosis in lifelong, veteran endurance athletes. J Appl Physiol (1985). 2011; 110: 1622-1626.

[41] Vágó H, Róka A, Acsády Gy, et al. Parasympathetic cardiac nerve stimulation with implanted coronary sinus lead. J Cardiovasc Electrophysiol. 2004; 15: 588-590.

[42] Soós P, Merkely B, Horvát PM, et al. Determinants and effects of electrical stimulation of the inferior interatrial parasympathetic plexus during atrial fibrillation. J Cardiovasc Electrophysiol. 2005; 16: 1362-1367.

[43] Spronk HM, De Jong AM, Verheule S, et al. Hypercoagulability causes atrial fibrosis and promotes atrial fibrillation. Eur Heart J. 2017; 38: 38-50.

[44] Fox CS, Parise H, D'Agostino RB, et al. Parental atrial fibrillation as a risk factor for atrial fibrillation in offspring. JAMA 2004; 291: 2851-2855.

[45] Mommersteeg MT, Brown NA, Prall OW, et al. Pitx2c and $N k x 2-5$ are required for the formation and identity of the pulmonary myocardium. Circ Res. 2007; 101: 902-909.

[46] Lubitz SA, Ozcan C, Magnani JW, et al. Advances in the genetics of atrial fibrillation: Implications for future research directions and personalized medicine. Circ Arrhythm Electrophysiol. 2010; 3: 291-299.

[47] Tucker NR, Ellinor PT. Emerging directions in the genetics of atrial fibrillation. Circ Res. 2014; 114: 1469-1482.

[48] Gudbjartsson DF, Holm H, Sulem P, et al. A frameshift deletion in the sarcomere gene MYL4 causes early-onset familial atrial fibrillation. Eur Heart J. 2017; 38: 27-34.

[49] Kopecky SL, Gersh BJ, McGoon MD, et al. The natural history of lone atrial fibrillation: a population-based study over three decades. N Engl J Med. 1987; 317: 669-674.

[50] Godtfredsen J. (ed.) Atrial fibrillation: Etiology, course and prognosis: A follow-up study of 1212 cases. Munksgaard International Publishers Ltd., Copenhagen, 1975.

[51] Lee SS, Kong KA, Kim D, et al. Clinical implication of an impaired fasting glucose and prehypertension related to new onset atrial fibrillation in a healthy Asian population without underlying disease: a nationwide cohort study in Korea. Eur Heart J. 2017; 38: 2599-2607.

[52] Schmitt J, Duray G, Gersh BJ, et al. Atrial fibrillation in acute myocardial infarction: a systematic review of the incidence, clinical features and prognostic implications. Eur Heart J. 2009; 30: $1038-1045$.

[53] Frost L, Hune LJ, Vestergaard P. Overweight and obesity as risk factors for atrial fibrillation or flutter: the Danish Diet, Cancer, and Health Study. Am J Med. 2005; 118: 489-495.

[54] Zhang L, Hou Y, Po SS. Obstructive sleep apnoea and atrial fibrillation. Arrhythm Electrophysiol Rev. 2015; 4: 14-18.

(Kugler Szilvia dr., Budapest, Városmajor u. 68., 1122 e-mail: kugler.szilvia@med.semmelweis-univ.hu) feltéve, hogy az eredeti szerző és a közlés helye, illetve a CC License linkje és az esetlegesen végrehajtott módosítások feltüntetésre kerülnek. 